\title{
Quality of cheese produced with milk from cows fed forage palm with different forages
}

\section{Qualidade do queijo produzido com leite de vacas alimentadas com palma forrageira com diferentes volumosos}

\author{
Camila Soares ${ }^{1}$; Vicente Ribeiro Rocha Júnior²*; Luciana Albuquerque Caldeira; \\ Lucas Daniel Alcântara Borges ${ }^{1}$; José Reinaldo Mendes Ruas²; Joyce Cipriana \\ Pacheco Ramos; ${ }^{3}$ Wilton Felipe Siqueira Santos ${ }^{4}$; Guilherme Henrique Silva \\ Walber de Oliveira Rabelo ${ }^{1}$
}

\begin{abstract}
The objective of this study was to evaluate the effects of forage palm combined with different forages in the diet of F1 Holstein x Zebu cows, on the quality of Minas Frescal cheese. Two simultaneous $4 \mathrm{x}$ 4 Latin squares were used in the experimental design. The treatments consisted of sorghum silage as the sole forage source; replacement of $50 \%$ sorghum silage by forage palm; elephant grass as the only forage source; $50 \%$ replacement of elephant grass by forage palm. Milk samples from each cow were analyzed for the chemical composition and the milk was pasteurized for cheese production. The gross and adjusted yields, texture, chemical and sensorial characteristics and fatty acid profile were evaluated. The chemical composition of the cheese was not influenced by the diets, as well as the sum of saturated, monounsaturated and polyunsaturated fatty acids. However, a lower stearic acid content was found in cheese from the milk of cows fed grass with forage palm and a lower value of conjugated linoleic acid for the diet with silage alone. In the consumer preference ranking test, the most preferred cheese was that of the sorghum silage diet and the least preferred was that of the sorghum silage/forage palm diet. In the overall impression, higher scores were assigned to cheeses of the treatments with exclusive silage or elephant grass. The replacement of 50\% sorghum silage or elephant grass by the forage palm did not change the chemical composition of the Minas Frescal cheese, however, it modified the profile of fatty acids and decreased the acceptance and preference of cheese by the consumers.
\end{abstract}

Key words: Fatty acids. Sensory analysis. F1 Holstein/Zebu cows.

\section{Resumo}

Objetivou-se avaliar os efeitos da palma forrageira em associação a diferentes volumosos, na dieta de vacas F1 Holandês x Zebu, sobre a qualidade do queijo Minas Frescal. No delineamento experimental foram utilizados dois quadrados latinos 4 x 4, simultâneos. Os tratamentos foram assim definidos:

1 Mestres em Zootecnia, Universidade Estadual de Montes Claros, UNIMONTES, Janaúba, MG, Brasil. E-mail: camila_ soarestur@hotmail.com; lucasdab@live.com; walberzoo@hotmail.com

2 Profs., UNIMONTES, Janaúba, MG, Brasil. E-mail: vicente.rocha@unimontes.br; luciana.caldeira@unimontes.br; jose.ruas@ unimontes.br

3 Discente, Curso de Mestrado, Programa de Pós-Graduação em Zootecnia, UNIMONTES, Janaúba, MG, Brasil. E-mail: joyceramos.zootec@gmail.com

4 Discentes, Curso de Graduação em Zootecnia, UNIMONTES, Janaúba, MG, Brasil. E-mail: wilton_felipe10@outlook.com; guilhermesilvahenrique1@hotmail.com

* Author for correspondence 
silagem de sorgo como única fonte volumosa; substituição de $50 \%$ da silagem de sorgo por palma forrageira; capim-elefante como única fonte volumosa; substituição de $50 \%$ do capim-elefante pela palma forrageira. As amostras de leite de cada vaca foram analisadas quanto à composição química e o leite foi pasteurizado para fabricação do queijo, sendo avaliados rendimentos bruto e ajustado, textura, características químicas e sensoriais e perfil de ácidos graxos. A composição química do queijo não foi influenciada pelas dietas, assim como os somatórios de ácidos graxos saturados, monoinsaturados e poli-insaturados. Entretanto, menor teor do ácido esteárico foi observado no queijo proveniente do leite das vacas alimentadas com capim com palma e menor valor de ácido linoleico conjugado para dieta com apenas silagem. No teste de ordenação de preferência pelos consumidores, o queijo mais preferido foi o da dieta com silagem de sorgo e o menos preferido o da dieta com silagem de sorgo/ palma. Na impressão global, maiores notas foram dadas para os queijos dos tratamentos com silagem e capim-elefante exclusivos. A substituição de $50 \%$ da silagem de sorgo ou capim-elefante pela palma forrageira não alterou composição química do queijo Minas Frescal, entretanto, modificou o perfil de ácidos graxos e diminuiu aceitação e preferência dos queijos pelos consumidores.

Palavras-chave: Ácidos graxos. Análise sensorial. Vacas F1 Holandês/Zebu.

\section{Introduction}

Among the products derived from milk processing, Minas Frescal cheese stands out as one of the most consumed in the country (IBGE, 2010). To maintain the quality standard in its production, in addition to the adequate processing, it is fundamental the quality of the raw material, which can be influenced, among other factors, by the diet of the animal (MARTINS et al., 2012; MELO et al., 2017; SOUZA et al., 2015).

The interest in the cultivation and knowledge of forage palm has been growing in recent years by the rural producers involved in dairy farming in the arid and semi-arid regions of the country (FERREIRA et al., 2009; SILVA et al., 2007; SOUZA et al., 2010). The forage palm adapts to the adverse conditions of the semi-arid region, due to its physiology characterized by the photosynthetic process called Crassulacean Acid Metabolism (CAM), which is expressed with greater intensity under conditions of severe abiotic stresses (GALVÃO JÚNIOR et al., 2014). Forage palm is a food rich in non-fiber carbohydrates $(60.7 \%)$ and has a high content of mineral matter $(10.21 \%)$, besides being a source of water, with $90 \%$ moisture (WANDERLEY et al., 2002). Cavalcante et al. (2008) demonstrated the potential of forage palm to replace traditional forage sources in herd feeding (CAVALCANTE et al., 2008). However, forage palm cannot be supplied exclusively to animals because it has limitations on protein and fiber value (GALVÃO JÚNIOR et al., 2014). The exclusive use of forage palm in the diet or in excessive amounts can cause digestive disorders, as well as soft stools and decreased rumination (WANDERLEY et al., 2002). Therefore, the use of forage palm in the forage fraction of the diet of lactating cows should be evaluated with caution, as it may impair the quality of milk and its derivatives, considering that the drop in milk fat content may be related to abnormal ruminal fermentation due to excess concentrate or low amount of fiber in the diet, with a decrease in $\mathrm{pH}$ and alteration in the ruminal acetate: propionate ratio.

According to Nudda et al. (2014), one of the major dietary factors related to modifications of milk fatty acid composition is related to changes in the forage fraction of the diet and the milk processing does not cause a substantial change in this composition. In the literature, the determination of the fatty acid profile of the cheese and the milk from cows fed diets containing forage palm was not found, requiring research to evaluate the influence of the use of this forage on the lipid quality of the milk and its derivatives.

The goal of this study was to evaluate the effects of the use of forage palm combined with different forages in the diet of F1 Holstein $x$ Zebu cows on the quality of the Minas Frescal cheese. 


\section{Material and Methods}

All procedures involving animals were approved by the institutional committee on animal use (protocol number under registration 138/2017). The experiment was conducted at the Experimental Farm of the State University of Montes Claros - UNIMONTES, located in the municipality of Janaúba, in the north of the State of Minas Gerais, where the climate is Aw, characterized by rainy summers and dry winters.

Eight F1 Holstein x Zebu cows with $72 \pm 11$ days of lactation were used at the beginning of the experiment. The experimental design was two simultaneous $4 \times 4$ Latin squares, each composed of four animals, four treatments and four experimental periods. Four experimental diets were used: Treatment 1 - Diet without forage palm (Opuntia ficus indica Mill), with sorghum silage as forage; Treatment 2 - Diet with $50 \%$ substitution of sorghum silage by forage palm; Treatment 3 - Diet without inclusion of forage palm, having elephant grass $\mathrm{cv}$. Roxo as the only forage source; Treatment 4 - Diet with $50 \%$ substitution of elephant grass cv. Roxo by forage palm. The forage: concentrate ratio, in the total dry matter (DM) of the diet, was 75:25. The experiment lasted 72 days, divided into four periods of 18 days; the first 14 days of each period to adapt the animals to the diets and the last four days for data collection and sampling. The diets were prepared to be isoproteic to meet cows with an average of 550 $\mathrm{kg}$ body weight and average production of $15 \mathrm{~kg}$ of milk corrected to $3.5 \%$ fat day ${ }^{-1}$ and were fed to cows twice a day at $07 \mathrm{~h}$ and at $13 \mathrm{~h}$, in a complete diet system. The urea was used to correct the crude protein content of the forage fraction of the diets, using a single concentrate in the four experimental diets. To ensure the maintenance of the forage: concentrate ratio in the total DM of the diets and that they were kept isoproteic, the DM and crude protein $(\mathrm{PB})$ contents of the forages were analyzed weekly, according to Detmann et al. (2012).

The forage palm used was the species Opuntia ficus-indica Mill, cv. Gigante obtained from the Agricultural Research Company of Minas Gerais (EPAMIG), located in the municipality of Nova Porteirinha. The foods offered daily were weighed on a digital scale and the supply was adjusted so that the leftovers represented $5 \%$ of the amount of dry matter supplied. The proportion of the ingredients used in the diets and their chemical composition are listed in table 1 . The analyses were performed as described in Detmann et al. (2012).

Table 1. Proportion of the ingredients of the experimental diets $(\%)$ and chemical composition of the diets, on a dry matter basis.

\begin{tabular}{lcccc}
\hline \multirow{2}{*}{\multicolumn{1}{c}{ Ingredients }} & \multicolumn{4}{c}{ Experimental diets (\% DM) } \\
\cline { 2 - 5 } & Sorghum silage & Silage + forage palm & Elephant grass & Grass + forage palm \\
\hline Sorghum silage & 75 & 37.5 & 0 & 0 \\
Elephant grass & 0 & 0 & 75 & 37.5 \\
Forage palm & 0 & 37.5 & 0 & 37.5 \\
Ground corn & 17.01 & 17.01 & 17.01 & 17.01 \\
Soybean meal & 7.12 & 7.12 & 7.12 & 7.12 \\
Mineral supplement $^{1}$ & 0.87 & 0.87 & 0.87 & 0.87 \\
\hline \multicolumn{4}{c}{ Chemical Composition (\% DM) } \\
\hline Dry matter (\%) & 47.41 & 38.07 & 38.19 & 33.46 \\
Crude protein (\%) & 11.17 & 11.18 & 11.49 & 11.22 \\
Ether extract (\%) & 2.44 & 2.27 & 2.53 & 2.25 \\
Non-fiber carbohydrates & 25.35 & 40.68 & 20.09 & 39.17
\end{tabular}

continue 
continuation

\begin{tabular}{lcccc}
$\mathrm{NDFcp}^{2}(\%)$ & 52.39 & 38.12 & 56.89 & 40.43 \\
Lignin (\%) & 8.32 & 6.44 & 8.43 & 6.5 \\
\hline
\end{tabular}

${ }^{1}$ Guaranteed Levels per kg of product: calcium (128g min), phosphorus (100g min), sodium (120g min), magnesium (15g), sulfur (33g), cobalt (135mg), copper (2160mg), iron (938 mg), iodine (160 mg), manganese (1,800 mg), selenium (34 mg), zinc (5,760 $\mathrm{mg})$, fluorine $(1,000 \mathrm{mg}) ;{ }^{2} \mathrm{NDF} p \mathrm{p}=$ Neutral detergent fiber corrected for ash and protein; Mean percentages of Urea/SA (9: 1) in dry matter of forage fractions of diets: $0.72 \%$ (sorghum silage), $1.07 \%$ (silage with forage palm), $0.3 \%$ (elephant grass), $0.6 \%$ (grass with forage palm).

Cows were kept in individual stalls and milked with a mechanical milking machine (semi open) twice a day at $8 \mathrm{~h}$ and $14 \mathrm{~h}$. The presence of the calf was used to stimulate milk secretion and, after milking, they remained with the dams to suckle the residual milk. To characterize the milk from each experimental diet, samples were collected twice a day, during the last four days of each period, and a pool of morning and afternoon milk samples was made in proportion to the amount produced.
In flasks containing Bronopol preservative, $50 \mathrm{~mL}$ milk samples were added and homogenized for later referral to Milk Clinics, a branch of the Animal Sciences Department of the "Luiz de Queiroz" School of Agriculture, University of São Paulo, located in Piracicaba, State of São Paulo, where the levels of fat, protein, lactose, total dry extract (TDE) and defatted dry extract (DDE) were determined by the infrared method (Table 2).

Table 2. Chemical composition of the milks from each experimental diet used to prepare the Minas Frescal cheese.

\begin{tabular}{lcccc}
\hline \multirow{2}{*}{ Variables } & \multicolumn{4}{c}{ Treatments } \\
\cline { 2 - 5 } & Sorghum silage & Silage + forage palm & Elephant grass & Grass + forage palm \\
\hline Fat $(\%)$ & 4.31 & 4.64 & 4.19 & 4.23 \\
Protein $(\%)$ & 3.39 & 3.40 & 3.29 & 3.30 \\
Lactose (\%) & 4.56 & 4.46 & 5.50 & 4.49 \\
TS $(\%)^{\prime}$ & 13.26 & 13.52 & 12.93 & 12.99 \\
DDE $(\%)^{2}$ & 8.95 & 8.88 & 8.75 & 8.76 \\
\hline
\end{tabular}

${ }^{1}$ Total Solids Content, ${ }^{2}$ Defatted Dry Extract Content.

Minas Frescal cheese was produced in the Laboratory of Technology of Animal Products of UNIMONTES - Campus Janaúba, according to the following production flow:

1) The milk from each experimental diet, separately, was weighed, filtered and subjected to slow pasteurization $\left(65^{\circ} \mathrm{C}\right.$ for 30 minutes $)$.

2) The milk was cooled to $39^{\circ} \mathrm{C}$, when calcium chloride $(40 \mathrm{~mL} / 100 \mathrm{~L})$ and rennet $(30 \mathrm{~mL} / 100 \mathrm{~L})$ were added, which was diluted in equal parts of filtered water.
3) After 40 - 60 minutes, milk coagulation occurred

4) The mass was cut with a stainless-steel knife in cubes of 1.5 to $2 \mathrm{~cm}$, intercalating the stirring and the rest to promote the whey draining.

5) The mass was put into plastic forms and salted $(700 \mathrm{~g} / 100 \mathrm{~L}$ of refined white salt).

6) The cheeses were cooled to a temperature of $4^{\circ} \mathrm{C}$ for approximately 12 hours.

7) The cheeses were removed from the forms, packed, weighed on a digital scale for yield 
determination and reserved for further analysis of texture, chemical and sensory composition.

Samples of cheeses from each treatment were frozen and sent to the Laboratory of Animal Nutrition and Growth - ESALQ - USP where the profile of fatty acids was determined.

The gross yield was calculated by the formula: Gross yield $(\mathrm{kg} / \mathrm{kg})=$ formulation weight (milk plus ingredients) $(\mathrm{kg}) /$ mass of cheese after packaging $(\mathrm{kg})$. The yield adjusted for the moisture content of the cheese was calculated considering a value of $57 \%$ as reference for the moisture of the Minas Frescal cheese, according to the equation: Adjusted Yield $(\mathrm{L} / \mathrm{kg})=$ milk volume $(\mathrm{L}) \times(100-$ $\%$ intended moisture) / ( $\mathrm{kg}$ cheese $\mathrm{x}$ solid content (\%) (FURTADO, 2005). The texture of the cheese samples was determined using a Texturometer Stabic Micro Systems, TAXT Model, with the aid of a Software, providing the cutting force $(\mathrm{kg})$. It was used a Probe Warner Bratzler cell with a speed of $3 \mathrm{~mm} / \mathrm{second}$. To determine the chemical characteristics of the cheese, the following analyses were performed in triplicate: titratable acidity $\left({ }^{\circ} \mathrm{D}\right)$, using a phenolphthalein indicator solution $(0.1 \%)$, $\mathrm{pH}$ by means of the Tecnopon digital pHmeter, percentage fat content by the Gerber method, protein by the Kjeldahl method, fixed mineral residue, by the elimination of organic matter at $550^{\circ} \mathrm{C}$; total solids by evaporating water from the sample using an oven at $105^{\circ} \mathrm{C}$ and the moisture was determined by subtraction of the total solids; and water activity (Aw) by means of Aw meter, AquaLab ${ }^{\circledR}$ model.

In order to determine the fatty acid profile, transmethyled samples of cheeses were analyzed by a Finnigan Focus GC Gas Chromatograph with flame ionization detector, CP-Sil 88 capillary column (Varian), $100 \mu \mathrm{m}$ long, $0.25 \mu \mathrm{m}$ internal diameter and $0.20 \mu \mathrm{m}$ film thickness. Fatty acids were identified by comparing the retention times of the methyl esters of the samples with fatty acid patterns of butter. The fatty acids were quantified by normalizing the areas of the methyl esters. The results of the fatty acids were expressed in $\mathrm{mg} / \mathrm{g}$ of fat.

The nutritional quality of the lipid fraction of the cheese was evaluated by the fatty acid composition data, using the following calculations: Atherogeneity Index $(\mathrm{AI})=\{(\mathrm{C} 12: 0+(4 \times \mathrm{C} 14: 0)+\mathrm{C} 16: 0)\} /$ ( $\Sigma$ monounsaturated fatty acids $+\Sigma \omega 6+\Sigma \omega 3)$ and Thrombogenicity Index $(\mathrm{TI})=(\mathrm{C} 14: 0+\mathrm{C} 16: 0+$ $\mathrm{C} 18: 0) /\{(0.5 \times \Sigma$ monounsaturated fatty acids $)+$ $(0.5 \times \Sigma \omega 6+(3 \times \Sigma \omega 3)+(\Sigma \omega 3 / \Sigma \omega 6)\}$, according to Ulbricht and Southgate (1991); the ratio of hypocholesterolemic to hypercholesterolemic fatty acids $(\mathrm{HH})=($ monounsaturated + polyunsaturated $) /$ $(\mathrm{C} 14: 0+\mathrm{C} 16: 0)$ and Desirable Fatty Acids (DFA) $=$ (unsaturated + C18: 0 ) according to Costa et al. (2008); the ratio of polyunsaturated fatty acids to saturated fatty acids and the ratio of $\omega 6$ to $\omega 3$ (COSTA et al., 2008).

Assessment of cheeses by untrained panelists was performed using the sensory acceptance test described by Meilgaard et al. (1999). The sensory analysis of cheeses was done in five periods, with 25 testers per period, the samples were coded and cut into cubes weighing $25 \mathrm{~g}$ and supplied in disposable cups. The samples with their respective codes were simultaneously served and classified by the tasters to evaluate the general acceptance of the same, assigning the score 1 for the least accepted and 9 for the most accepted. The preference ranking test followed the methodology described by Meilgaard et al. (1999).

Data were tested by analysis of variance and, when significant, the means of the treatments were compared by Tukey's test, considering $\alpha=0.05$. For preference ranking of the cheese samples, data were subjected to the minimum significant difference analysis, considering $\alpha=0.05$.

\section{Results and Discussion}

The chemical composition of the Minas Frescal cheese presented no differences for fat, protein, 
total solids (TS), moisture and fixed mineral residue (FMR) between diets with and without the presence of forage palm (Table 3). The moisture of the cheeses presented results according to the current legislation that classifies Minas Frescal cheese as being of very high moisture, that is, moisture of not less than 55\% (BRASIL, 2004). A mean value of 57.74\% moisture was observed for the cheeses obtained in this study (Table 3).

Table 3. Chemical composition, gross yield and adjusted yield for the moisture content of the Minas Frescal cheese produced with milk from F1 Holstein x Zebu cows fed forage palm combined with different forages.

\begin{tabular}{|c|c|c|c|c|c|c|c|}
\hline \multirow[b]{2}{*}{ Variables } & \multicolumn{7}{|c|}{ Treatments } \\
\hline & $\begin{array}{l}\text { Sorghum } \\
\text { silage }\end{array}$ & $\begin{array}{c}\text { Silage } \\
+ \text { forage palm }\end{array}$ & $\begin{array}{c}\text { Elephant } \\
\text { grass }\end{array}$ & $\begin{array}{l}\text { Grass }+ \text { forage } \\
\text { palm }\end{array}$ & $\begin{array}{l}\text { Overall } \\
\text { mean }\end{array}$ & $\mathrm{CV}(\%)$ & $\operatorname{Pr}>\mathrm{Fc}$ \\
\hline Moisture (\%) & 56.82 & 57.35 & 57.47 & 59.33 & 57.74 & 6.34 & 0.7842 \\
\hline${ }^{1} \mathrm{TSC}(\%)$ & 42.47 & 42.62 & 42.62 & 40.76 & 42.11 & 8.28 & 0.8455 \\
\hline Fat (\% TSC) & 33.2 & 32.64 & 30.07 & 28.02 & 30.97 & 16.09 & 0.4569 \\
\hline Protein (\% TSC) & 30.44 & 27.73 & 30.98 & 29.70 & 29.71 & 12.76 & 0.6501 \\
\hline${ }^{2} \mathrm{FMR}(\% \mathrm{TSC})$ & 7.55 & 6.20 & 6.18 & 7.98 & 6.97 & 21.29 & 0.2493 \\
\hline Titratable acidity (\%) & 0.61 & 0.51 & 0.45 & 0.45 & 0.50 & 23.07 & 0.2137 \\
\hline $\mathrm{pH}$ & 6.63 & 7.13 & 7.37 & 6.62 & 6.93 & 10.56 & 0.4125 \\
\hline Texture (Kg) & 1.20 & 0.80 & 0.89 & 0.99 & 0.97 & 21.34 & 0.0879 \\
\hline${ }^{3} \mathrm{GY}(\mathrm{kg} / \mathrm{kg})$ & 3.04 & 3.19 & 3.15 & 2.85 & 3.05 & 12.17 & 0.5933 \\
\hline${ }^{4} \mathrm{YA}(\mathrm{kg} / \mathrm{kg})$ & 2.32 & 2.40 & 2.38 & 2.20 & 2.32 & 16.59 & 0.8766 \\
\hline
\end{tabular}

Means followed by different letters in the same row are significantly different $(\mathrm{P}<0.05)$ by Tukey's test. ${ }^{1}$ total solids content, ${ }^{2}$ fixed mineral residue, ${ }^{3}$ gross yield of cheese, ${ }^{4}$ cheese yield adjusted for moisture.

The total dry extract (TDE) of the cheeses was on average $42.11 \%$. Similar results were found by Martins et al. (2012) working with cows fed different forages, obtaining a mean value of $43 \%$ TDE in Minas Frescal cheese. According to Brasil (2004), the Minas cheese protein can vary up to $40 \%$, proving that the cheeses obtained in this study are within the standards of identity and quality of cheeses in Brazil. In addition, they can be classified as semi-fatty, since they have between 28.02 and $33.9 \%$ fat in the total dry extract and, therefore, are within the standards required by current legislation (BRASIL, 2004). The studied diets confer, on average, $6.97 \%$ of fixed mineral residue in EST of Minas Frescal cheese (Table 3). The values of titratable acidity and $\mathrm{pH}$ were not influenced by the diets (Table 3). Figueiredo et al. (2015) evaluated characteristics of artisanal Minas Frescal cheese in different months of the year and reported $\mathrm{pH}$ values ranging from 4.69 to 5.31 . On the other hand,
Andreatta et al. (2009), who followed the same industrial cheesemaking process of this experiment, reported average values ranging from 6.67 to 6.74 , which are consistent with the results of the present study.

The cheese texture was also not influenced by the diets $(\mathrm{P}>0.05)$. According to O'Callaghan and Guinee (2004), the texture of cheese is one of the most important characteristics for defining the identity and acceptance of the product, because it is mainly through this property that consumers identify and judge each variety.

The combination of forage palm to different forage did not alter gross and adjusted yields for the moisture content of Minas Frescal cheese (Table 3). The protein content and, especially, the proportion of casein in the total milk protein has a determining influence on the yield. Thus, the absence of significance for yield was expected, since the 
protein content of the milks of each treatment were very close, as well as the fat and total solids contents (Table 2).

In the evaluation of the fatty acid profile of the Minas Frescal cheese, there was no influence of diet on the saturated fatty acids (SFA), monounsaturated fatty acids (MUFA) and polyunsaturated fatty acids (PUFA) $(\mathrm{P}<0.05)$ (Table 4). A mean proportion of saturated fatty acids of $76.75 \%$, monounsaturated fatty acids of $20.01 \%$ and polyunsaturated fatty acids of $1.65 \%$ was found. Among the class of saturated fatty acids in Minas Frescal cheese, there was a difference $(\mathrm{P}<0.05)$ for $\mathrm{C} 18$ : 0 (stearic) and C24: 0 (lignoceric) acids, both of which presented higher values in the diet which provided sorghum silage as exclusive forage. In general, saturated fat increases the plasma cholesterol concentration; however, stearic SFA (C18: 0) is considered to be neutral in its effects on cholesterol, which can be rapidly converted to oleic acid (monounsaturated), promoting a positive effect on human health due to its hypocholesterolemic function (COSTA et al., 2008).

Much of the saturated fatty acids in milk, with 18 or more carbons in the chain, originate from the diet. Among them, stearic acid normally has the highest levels in milk and milk products. The stearic acid content in milk fat is associated with the intake of this acid and the degree of ruminal biohydrogenation of polyunsaturated fatty acids, and this relationship occurs because stearic is the end product of this process (NUDDA et al., 2014). Thus, according to Soyeurt et al. (2008), the higher the stearic concentration in milk, the greater the biohydrogenation on the rumen polyunsaturated acids.

In the monounsaturated fatty acid class, a difference was found for the fatty acid C18: 1cis9 (oleic), with higher value in the treatment in which the cows received elephant grass as the sole forage source and a higher concentration of C18:1trans was observed for the diets in which elephant grass associated with forage palm and elephant grass alone. Moallem (2009) cites the accumulation of C18:1 trans in milk as a characteristic of incomplete biohydrogenation of fatty acids in the rumen. C18:1 trans specific isomers may be related to the depletion of de novo synthesis in the mammary gland.

The concentration of conjugated linoleic acid (CLA) (C18: 2c9 t11) in the cheese fat was lower with the diet with sorghum silage as exclusive forage compared to the other diets. On the other hand, the levels of C18: $3 n-3-\alpha$-linolenic acid also varied according to the diets $(\mathrm{P}<0.05)$, being higher with the diet based on sorghum silage in relation to the diets in which the forage palm was included.

Unlike saturated fatty acids, long-chain, monounsaturated and polyunsaturated fatty acids contribute to the increase of high-density cholesterol (HDL) (SANTOS et al., 2013). For the beneficial effects, stand out the unsaturated fatty acids oleic (C18: 1cis-9) and the isomers of conjugated linoleic acid (CLA), related to cholesterol reduction and anticarcinogenic effects, respectively (DILZER; PARK, 2012; LANIER; CORL, 2015). PUFAs are not synthesized by ruminant tissues, their concentration in milk is determined by the amount of these acids that reach the duodenum (NUDDA et al., 2014). In this study, the forage: concentrate ratio was fixed (75:25) and the same for all treatments, however, the diets with presence of forage palm presented higher contents of fast-fermenting carbohydrates, and lower fiber contents (Table 1), which may have caused lower ruminal $\mathrm{pH}$ values and increased passage rate, thus impairing the activity of the microorganisms responsible for the final metabolic steps of biohydrogenation of fatty acids, which may justify the lower content of stearic fatty acid in cheese for diets containing forage palm, as well as higher values of CLA and C18: 1 trans, which are intermediates of this process in the rumen.

According to Nudda et al. (2014), milk processing does not cause a significant change in the fatty acid 
profile and thus the fatty acid concentrations in the fat of milk derivatives are essentially dependent on the fatty acid profile of the milk before processing. The most significant changes in the FA profile of ruminant milk have been observed mainly by the variation in the number and types of forage, as well as by the addition of oil sources (MOURTHÉ et al., 2015; RIBEIRO et al., 2014), since they have an effect on the ruminal biohydrogenation of polyunsaturated fatty acids.

Table 4. Fatty acid profile of the fat of cheese from F1 Holstein x Zebu cows fed forage palm combined with different forages.

\begin{tabular}{|c|c|c|c|c|c|c|}
\hline \multirow[b]{2}{*}{ Components } & \multicolumn{5}{|c|}{ Treatments } & \multirow[b]{2}{*}{$\mathrm{Pr}>\mathrm{Fc}$} \\
\hline & $\begin{array}{l}\text { Sorghum } \\
\text { silage }\end{array}$ & $\begin{array}{c}\text { Silage } \\
+ \text { forage palm }\end{array}$ & Elephant grass & $\begin{array}{c}\text { Grass }+ \\
\text { forage palm }\end{array}$ & CV $(\%)$ & \\
\hline$\sum \mathrm{SFA}^{1}$ & 77.1747 & 76.8962 & 75.9552 & 77.0322 & 26.56 & 0.4230 \\
\hline C4:0 & 2.9247 & 2.9624 & 2.8502 & 2.9925 & 07.29 & 0.8955 \\
\hline C6:0 & 2.0212 & 2.0482 & 2.0352 & 2.0777 & 02.45 & 0.1345 \\
\hline C8:0 & 1.4082 & 1.3525 & 1.3510 & 1.4022 & 04.47 & 0.4220 \\
\hline C10:0 & 3.3890 & 3.2785 & 3.2592 & 3.4535 & 12.46 & 0.8974 \\
\hline C11:0 & 0.1867 & 0.1345 & 0.1967 & 0.1410 & 55.63 & 0.4688 \\
\hline C12:0 & 4.2432 & 4.2027 & 4.0217 & 4.4362 & 15.01 & 0.8334 \\
\hline $\mathrm{C} 13: 0$ iso & 0.0510 & 0.0457 & 0.0511 & 0.0510 & 13.05 & 0.5949 \\
\hline $\mathrm{C} 13: 0$ anteiso & 0.1532 & 0.1710 & 0.1742 & 0.1730 & 14.15 & 0.5773 \\
\hline $\mathrm{C} 13: 0$ & 0.1745 & 0.2082 & 0.1690 & 0.2325 & 23.93 & 0.2369 \\
\hline $\mathrm{C} 14: 0$ iso & 0.1585 & 0.1537 & 0.1500 & 0.1587 & 13.47 & 0.8878 \\
\hline C14:0 & 13.3052 & 13.1050 & 12.9437 & 13.2747 & 6.89 & 0.9364 \\
\hline $\mathrm{C} 15: 0$ iso & 0.3357 & 0.3147 & 0.3357 & 0.3122 & 15.60 & 0.1794 \\
\hline $\mathrm{C} 15: 0$ anteiso & 0.5515 & 0.5720 & 0.6185 & 0.5865 & 16.88 & 0.8046 \\
\hline $\mathrm{C} 15: 0$ & 1.0015 & 1.3537 & 1.2245 & 1.5827 & 42.95 & 0.5331 \\
\hline $\mathrm{C} 16: 0$ iso & 0.0662 & 0.0745 & 0.1285 & 0.1327 & 18.56 & 0.7934 \\
\hline C16:0 & 39.0757 & 40.7377 & 37.2860 & 40.4922 & 06.11 & 0.2123 \\
\hline $\mathrm{C} 17: 0$ iso & 0.3892 & 0.3810 & 0.3838 & 0.3925 & 8.57 & 0.3303 \\
\hline $\mathrm{C} 17: 0$ & 0.7645 & 0.7917 & 0.7232 & 0.7680 & 10.13 & 0.6613 \\
\hline C18:0 & $5.8605 \mathrm{a}$ & $4.8637 \mathrm{~b}$ & $5.5237 \mathrm{ab}$ & $4.5575 \mathrm{~b}$ & 10.07 & 0.0158 \\
\hline C20:0 & 0.0772 & 0.0642 & 0.0732 & 0.0645 & 30.70 & 0.4487 \\
\hline C22:0 & 0.0220 & 0.0237 & 0.0122 & 0.0255 & 58.84 & 0.4558 \\
\hline $\mathrm{C} 23: 0$ & 0.0242 & 0.0125 & 0.0232 & 0.0222 & 42.98 & 0.2612 \\
\hline $\mathrm{C} 24: 0$ & $0.042 \mathrm{a}$ & $0.0310 \mathrm{ab}$ & $0.0215 \mathrm{~b}$ & $0.0270 \mathrm{~b}$ & 20.61 & 0.0034 \\
\hline$\sum$ MUFA $^{2}$ & 16.0287 & 20.4705 & 23.3262 & 20.2522 & 27.80 & 0.3626 \\
\hline C10:1 & 0.3277 & 0.4165 & 0.4150 & 0.4237 & 28.96 & 0.6093 \\
\hline C12:1 & 0.0157 & 0.0967 & 0.0987 & 0.0785 & 31.10 & 0.6190 \\
\hline C14:1c9 & 1.5357 & 1.6575 & 1.6582 & 1.6302 & 13.90 & 0.8559 \\
\hline C16:1c9 & 2.5530 & 2.8755 & 2.6877 & 2.8900 & 11.21 & 0.3895 \\
\hline C17:1 & 0.1232 & 0.1220 & 0.1630 & 0.1935 & 87.36 & 0.8446 \\
\hline C18:1 c9 & $12.6997 \mathrm{~b}$ & $12.7550 \mathrm{~b}$ & $14.3665 \mathrm{a}$ & $12.640 \mathrm{~b}$ & 11.79 & 0.0405 \\
\hline $\mathrm{C} 18: 1$ trans & $0.8022 b$ & $0.8027 \mathrm{~b}$ & $1.0990 \mathrm{a}$ & $1.0981^{\mathrm{a}}$ & 15.73 & 0.0377 \\
\hline C18:1 c11 & 1.5645 & 1.3675 & 1.4857 & 1.2355 & 17.78 & 0.3178 \\
\hline $\mathrm{C} 18: 1 \mathrm{c} 12$ & 0.7270 & 0.6677 & 0.7105 & 0.6075 & 15.84 & 0.4319 \\
\hline C18:1 c13 & 0.3607 & 0.3527 & 0.3742 & 0.3045 & 15.34 & 0.3214 \\
\hline C18:1 t16 & 0.0785 & 0.0915 & 0.0942 & 0.0955 & 24.16 & 0.6790 \\
\hline
\end{tabular}


continuation

\begin{tabular}{lcccccc}
$\mathrm{C} 18: 1 \mathrm{c} 15$ & 0.0702 & 0.0667 & 0.0617 & 0.0672 & 38.51 & 0.9720 \\
$\mathrm{C} 20: 1$ & 0.0567 & 0.0237 & 0.0535 & 0.0450 & 35.82 & 0.2950 \\
$\mathrm{C} 22: 1 \mathrm{n} 9$ & 0.0502 & 0.0507 & 0.0505 & 0.0504 & 21.37 & 0.6951 \\
$\mathrm{C} 24: 1$ & 0.0072 & 0.0070 & 0.0071 & 0.0069 & 30.51 & 0.2513 \\
\hline$\Sigma \mathrm{AGPI}^{3}$ & 1.6400 & 1.6595 & 1.6297 & 1.7042 & 13.53 & 0.4259 \\
\hline $\mathrm{C} 18: 3 \mathrm{n} 6$ & 0.0037 & 0.0040 & 0.0032 & 0.0045 & 35.83 & 0.4593 \\
$\mathrm{C} 18: 3 \mathrm{n3}$ & $0.2407 \mathrm{a}$ & $0.1680 \mathrm{~b}$ & $0.1887 \mathrm{ab}$ & $0.1712 \mathrm{~b}$ & 13.56 & 0.0067 \\
$\mathrm{C} 18: 2 \mathrm{c} 9 \mathrm{t} 11(\mathrm{CLA})$ & $0.1850 \mathrm{~b}$ & $0.2090 \mathrm{ab}$ & $0.3285 \mathrm{a}$ & $0.2907 \mathrm{ab}$ & 26.72 & 0.0350 \\
$\mathrm{C} 20: 2$ & 0.0018 & 0.0020 & 0.0019 & 0.0018 & 59.39 & 0.2978 \\
$\mathrm{C} 20: 3 \mathrm{n} 6$ & 0.0370 & 0.0350 & 0.0217 & 0.0250 & 48.96 & 0.4053 \\
$\mathrm{C} 20: 4 \mathrm{n} 6$ & 0.0137 & 0.0115 & 0.0100 & 0.0142 & 55.42 & 0.8005 \\
$\mathrm{C} 20: 5 \mathrm{n} 3$ & 0.0125 & 0.0140 & 0.0102 & 0.0112 & 35.72 & 0.6445 \\
$\mathrm{C} 22: 5$ & 0.0250 & 0.0240 & 0.0277 & 0.0402 & 22.00 & 0.4609 \\
$\mathrm{C} 22: 6 \mathrm{n} 3$ & 0.0005 & 0.0002 & 0.0000 & 0.0020 & 51.06 & 0.3930 \\
\hline
\end{tabular}

Means followed by different letters in the same row are significantly different $(\mathrm{P}<0.05)$ by Tukey's test. 'Saturated fatty acids, ${ }^{2}$ Monounsaturated fatty acids, ${ }^{3}$ Polyunsaturated fatty acids.

In the present study, none of the nutritional quality indices of the Minas Frescal cheese lipid fraction was influenced by the diets evaluated (Table 5). Atherogenicity (AI) and thrombogenicity (TI) indices indicate the potential for stimulating platelet aggregation, the lower the $\mathrm{AI}$ and TI values, the greater the amount of antiatherogenic fatty acids present in a particular oil/fat and, consequently, the greater is the potential to prevent the onset of coronary heart disease. According to Bentes et al. (2009), there are no recommended values for AI and TI in dairy products, therefore, the lower the value of these indices, the more favorable is the fatty acid profile to human health.

Table 5. Atherogenic index (AI), thrombogenicity index (TI), hypo/hypercholesterolemic ratio $(\mathrm{h} / \mathrm{H})$, desirable fatty acids (DFA), polyunsaturated fatty acids/saturated fatty acids ratio (PUFA/SFA), sum of $\omega 6$ fatty acids and $\omega 6 / \omega 3$ ratio of cheese of crossbred cows fed forage palm combined with other forages.

\begin{tabular}{lcccccc}
\hline \multirow{2}{*}{ Variables } & \multicolumn{5}{c}{ Experimental diets } \\
\cline { 2 - 7 } & $\begin{array}{c}\text { Sorghum } \\
\text { silage }\end{array}$ & $\begin{array}{c}\text { Silage } \\
\text { +forage palm }\end{array}$ & $\begin{array}{c}\text { Elephant } \\
\text { grass }\end{array}$ & $\begin{array}{c}\text { Grass }+ \text { forage } \\
\text { palm }\end{array}$ & $\begin{array}{c}\text { CV } \\
(\%)\end{array}$ & $\operatorname{Pr}>\mathrm{Fc}$ \\
\hline $\mathrm{AI}$ & 4.7185 & 4.7300 & 4.0277 & 4.7585 & 20.15 & 0.2833 \\
$\mathrm{TI}$ & 1.6912 & 2.2167 & 1.9077 & 2.3067 & 28.25 & 0.4332 \\
$\mathrm{~h} / \mathrm{H}$ & 0.6647 & 0.4117 & 0.4952 & 0.4120 & 27.33 & 0.4262 \\
$\mathrm{DFA}$ & 25.7223 & 26.9637 & 30.4797 & 26.5140 & 20.08 & 0.4505 \\
PUFA/SFA & 0.0223 & 0.0235 & 0.0211 & 0.0199 & 32.35 & 0.4262 \\
$\omega 6$ & 0.0600 & 0.0437 & 0.0410 & 0.0472 & 44.08 & 0.6088 \\
$\omega 6 / \omega 3$ & 0.3545 & 0.2152 & 0.2065 & 0.2602 & 47.20 & 0.5623 \\
\hline
\end{tabular}

Means followed by different letters in the same row are significantly different $(\mathrm{p}<0.05)$ by tukey's test.

In the sensory analysis of Minas Frescal cheese, differences were detected for the acceptance test (Table 6), using a nine-point hedonic scale. For appearance, a higher score was assigned to the cheese from milk of cows fed diet containing only sorghum silage as forage, indicating that the tasters moderately liked the same. However, tasters liked the appearance of all cheeses, although slightly, for diets containing forage palm. 
Table 6. Results of the acceptance test in the sensory analysis of the Minas Frescal cheese produced from the milk of F1 Holstein x Zebu cows fed forage palm combined with different sources of forage.

\begin{tabular}{ccccc}
\hline \multirow{2}{*}{ Variables } & \multicolumn{4}{c}{ Treatments } \\
\cline { 2 - 5 } & Sorghum silage & Silage + forage palm & Elephant grass & Grass + forage palm \\
\hline Appearance & $7.2 \mathrm{a}$ & $6.54 \mathrm{~b}$ & $7.15 \mathrm{ab}$ & $6.06 \mathrm{~b}$ \\
Consistency & $6.5 \mathrm{a}$ & $6.14 \mathrm{a}$ & $6.6^{\mathrm{a}}$ & $5.28 \mathrm{~b}$ \\
Taste & $7.22 \mathrm{a}$ & $6.68 \mathrm{a}$ & $6.75^{\mathrm{a}}$ & $5.91 \mathrm{~b}$ \\
$\mathrm{OI}^{1}$ & $7.03 \mathrm{a}$ & $6.5 \mathrm{ab}$ & $6.85^{\mathrm{a}}$ & $5.93 \mathrm{~b}$ \\
\hline $\mathrm{N}^{2}$ & 100 & 100 & 100 & 100
\end{tabular}

Means followed by different letters in the same row are significantly different $(\mathrm{p}<0.05)$ by Tukey's test. ${ }^{1}$ Overall impression, ${ }^{2}$ number of tasters.

When analyzed for consistency and flavor, higher scores were for the cheeses of the treatments with only sorghum silage or sorghum silage and forage palm, and only elephant grass. For overall impression, higher scores were given to the cheese from treatments with exclusive silage and exclusive elephant grass, differing from the treatment where grass combined with forage palm was offered. Values that approximate scale 7 (moderately liked) indicate satisfactory results for the acceptance test, which occurred in the present study, for appearance, in all diets supplied, however, for consistency, taste and overall impression, results found in treatment with $50 \%$ substitution of elephant grass by forage palm, were lower than 6 , showing a negative influence for cheeses from the milk of cows fed this diet. For the preference ranking test (Table 7), there was a difference $(\mathrm{P}<0.05)$ between the treatments, showing that the most preferred cheese was the diet without forage palm inclusion, with sorghum silage as forage, and the least preferred was that of the diet with $50 \%$ substitution of sorghum silage by forage palm. The forage palm in $37.5 \%$ of the total dietary dry matter may have provided sensory changes to the Minas Frescal cheese, which were perceptible to the tasters.

Table 7. Result of the preference ranking test of the sensory analysis of the Minas Frescal cheese produced from the milk of F1 Holstein x Zebu cows fed forage palm combined with different sources of forage.

\begin{tabular}{ccccc}
\hline & \multicolumn{4}{c}{ Treatments } \\
\cline { 2 - 5 } & Sorghum silage & Silage + forage palm & Elephant grass & Grass + forage palm \\
\hline Sum of Orders & $207 \mathrm{a}$ & $359 \mathrm{c}$ & $243 \mathrm{ab}$ & $278 \mathrm{bc}$ \\
$\mathrm{N}^{2}$ & 100 & 100 & 100 & 100 \\
\hline
\end{tabular}

Totals with the same letter in the row are not significantly different $(\mathrm{p}<0.05)$ when evaluating the least significant difference (LSD); ${ }^{2}$ Number of tasters.

According to Costa et al. (2009), there are many factors that may interfere with the sensory characteristics of cheese, among these factors, the fat is highlighted, and these changes do not only occur in relation to its content, but also to the composition, acting mainly on color, odor, taste and brightness of the dairy derivative.

\section{Conclusions}

The substitution of $50 \%$ sorghum silage or elephant grass by the forage palm did not change the chemical composition of the Minas Frescal cheese, however, it modified the profile of fatty acids and decreased the acceptance and preference of the cheeses by the consumers. 


\section{Acknowledgements}

To FAPEMIG, CAPES and CNPq, for assistance with scholarships and research grants, to EPAMIG - Nova Porteirinha, and to INCT-Animal Science.

\section{References}

ANDREATTA, E.; FERNANDES, A. M.; SANTOS, M. V. D.; MUSSARELLI, C.; MARQUES, M. C.; GIGANTE, M. L.; OLIVEIRA, C. A. F. Quality of Minas Frescal cheese prepared from Milk with differents somatic cell counts. Pesquisa Agropecuária Brasileira, Brasília, v. 44, n. 3, p. 320-326, 2009.

BENTES, A. S.; SOUZA, H. A. L.; SIMÕES, M. G.; MENDONÇA, X. M. F. Caracterização física e química e perfil lipídico de três espécies de peixes amazônicos. Revista Brasileira de Tecnologia Agroindustrial, Ponta Grossa, v. 3, n. 2, p. 97-108, 2009.

BRASIL. Ministério da Agricultura, Pecuária e Abastecimento. Regulamento técnico para fixação de identidade e qualidade de queijos. Instrução Normativa $\mathrm{n}^{\circ}$ 4, de 01 de março de 2004. Brasília: MAPA, 2004. 1 p.

CAVALCANTE, C. V. A.; FERREIRA, M. A.; CARVALHO, M. C.; VÉRAS, A. S. C.; SILVA, F. M.; LIMA, L. E. Palma forrageira enriquecida com uréia em substituição ao feno de capim tifton 85 em rações para vacas da raça Holandesa em lactação. Revista Brasileira de Zootecnia, Viçosa, MG, v. 37, n. 4, p. 689-693, 2008.

COSTA, R. G.; MESQUITA, I. V. U.; QUEIROGA, R. C. R. E.; MEDEIROS, A. N.; CARVALHO, F. F. R.; BELTRÃO FILHO, E. M. Características químicas e sensoriais do leite de cabras Moxotó alimentadas com silagem de maniçoba. Revista Brasileira de Zootecnia, Viçosa, MG, v. 37, n. 4, p. 694-702, 2008.

COSTA, R. G.; QUEIROGA, R. C. R. E.; PEREIRA, R. A. G. Influência do alimento na produção e qualidade do leite de cabra. Revista Brasileira de Zootecnia, Viçosa, MG, v. 38, n. 4, p. 307-321, 2009.

DETMANN, E.; SOUZA, M. D.; VALADARES FILHO, S. D. C.; QUEIROZ, A. D.; BERCHIELLI, T. T.; SALIBA, E. O. S.; AZEVEDO, J. A. G. Métodos para análise de alimentos. Visconde do Rio Branco: Suprema, 2012. $214 \mathrm{p}$.

DILZER, A.; PARK, Y. Implication of Conjugated Linoleic Acid (CLA) in human health. Food Science and Nutrition, London, v. 52, n. 6, p. 488-513, 2012.

FERREIRA, M. A.; SILVA, F. M.; BISPO, S. V.; AZEVEDO, M. Estratégias na suplementação de vacas leiteiras no semi-árido do Brasil. Revista Brasileira de Zootecnia, Viçosa, MG, v. 38, n. 4, p. 322-329, 2009.

FIGUEIREDO, S. P.; BOARI, C. A.; SOBRINHO, P. D. S. C.; CHAVES, A. C. S. D.; SILVA, R. B.; SILVA, H. B. F. Características do leite cru e do queijo minas artesanal do serro em diferentes meses. Archives of Veterinary Science, Curitiba, v. 20, n. 1, p. 68-82, 2015.

FURTADO, M. M. Principais problemas dos queijos: causas e prevenção. São Paulo: Fonte, 2005. 200 p

GALVÃO JÚNIOR, J. G. B.; SILVA, J. B. A.; MORAIS, J. H. G.; LIMA, R. N. Palma forrageira na alimentação de ruminantes: cultivo e utilização. Acta Veterinária Brasilica, Mossoró, v. 8, n. 2, p. 78-85, 2014.

INSTITUTO BRASILEIRO DE GEOGRAFIA E ESTATÍSTICA - IBGE. Pesquisa de orçamentos familiares 2008-2009. Aquisição alimentar domiciliar per capita: Brasil e Grandes Regiões. Rio de Janeiro: Instituto Brasileiro de Geografia e Estatística, 2010.

LANIER, J. S.; CORL, B. A. Challenges in enriching milk fat with polyunsaturated fatty acids. Journal of Animal Science and Biotechnology, Beijing, v. 6, n. 1, p. 1-26, 2015.

MARTINS, S. C. S.; ROCHA JÚNIOR, V. R.; CALDEIRA, L. A.; REIS, S. T.; BARROS, I. C.; OLIVEIRA, J. A.; SANTOS, J. F.; SILVA, G. W. V. Yield, composition and sensory analysis of Minas cheese made with milk from crossbred cows fed different roughages. Revista Brasileira de Zootecnia, Viçosa, MG, v. 41, n. 4, p. 27-48, 2012.

MEILGAARD, M.; CIVILLE, G. V.; CARR, B. T. Sensory evaluation techniques. Boca Raton: CRC Press, 1999. v. 2, 387 p.

MELO, M. T. P.; ROCHA JUNIOR, V. R.; CALDEIRA, L. A.; PIMENTEL, P. R. S.; REIS, S. T.; JESUS, D. L. S. Cheese and milk quality of F1 Holstein x Zebu cows fed different leves of banana peel. Acta Scientiarum. Animal Sciences, Maringá, v. 39, n. 2, p. 181-187, 2017.

MOALLEM, U. The effects of extruded flax seed suplementation to high-yielding dairy cows on milk production and milk fatty acid composition. Animal Feed Science and Technology, Braunschweig, v. 152, n. 3-4, p. 232-242, 2009.

MOURTHÉ, M. H. F.; REIS, R. B.; GAMA, M. A. S.; BARROS, P. A. V.; ANTONIASSI, R.; BIZZO, H. R.; LOPES, F. C. F. Perfil de ácidos graxos do leite de vacas Holandês x Gir em pastagem de capim-marandu suplementado com quantidades crescentes de grão de soja tostado. Arquivo Brasileiro de Medicina Veterinária e Zootecnia, Belo Horizonte, v. 67, n. 4, p. 1150-1158, 2015. 
NUDDA, A.; BATTACONE, G.; BOAVENTURA NETO, O.; CANNAS, A.; FRANCESCONI, A. H. D.; ATZORI, A. S.; PULINA, G. Feeding strategies to desing the fatty acid profile of sheep Milk and cheese. Revista Brasileira de Zootecnia, Viçosa, MG, v. 43, n. 8, p. 445-456, 2014.

O’CALLAGHAN, D. J.; GUINEE, T. P. Rheology and texture of cheese. In: FOX, P. F.; MCSWEENEY, P. L. H.; COGAN, T. M.; GUINEE, T. P. (Ed.). Cheese: chemistry, physics and microbiology. $3^{\text {th }}$ ed. London: Elsevier Academic Press, 2004. p. 511-540.

RIBEIRO, C. G. S.; LOPES, F. C. F.; GAMA, M. A. S.; MORENZ, M. J. F.; RODRIGUEZ, N. M. Desempenho produtivo e perfil de ácidos graxos do leite de vacas que receberam níveis crescentes de óleo de girassol em dietas à base de capim-elefante. Arquivo Brasileiro de Medicina Veterinária e Zootecnia, Belo Horizonte, v. 66, n. 5, p. 1513-1521, 2014.

SANTOS, R. D.; GAGLIARDI, A. C. M.; XAVIER, H. T.; MAGNONI, C. D.; CASSANI, R.; LOTTENBERG, A. M. P.; CASELlA FILHO, A.; ARAÚJO, D. B.; CESENA, F. Y.; ALVES, R. J.; FENELON, G.; NISHIOKA, S. A. D.; FALUDI, A. A.; GELONEZE, B.; SCHERR, C.; KOVACS, C.; TOMAZZELA, C.; CARLA, C.; BARRERA-ARELLANO, D.; CINTRA, D.; QUINTÃO, E.; NAKANDAKARE, E. R.; FONSECA, F. A. H.; PIMENTEL, I.; SANTOS, J. E.; BERTOLAMI, M. C.; ROGERO, M.; IZAR, M. C.; NAKASATO, M.; DAMASCENO, N. R. T.; MARANHÃO, R.; CASSANI, R. S. L.; PERIM, R.; RAMOS, S. Sociedade brasileira de cardiologia: I diretriz sobre o consumo de gorduras e saúde cardiovascular. Arquivos Brasileiros de Cardiologia, São Paulo, v. 100, p. 1-40, 2013. Suplemento 3.
SILVA, R. R.; FERREIRA, M. A.; VÉRAS, A. S. C.; RAMOS, A. O.; MELO, A. A. S.; GUIMARÃES, A. V. Palma forrageira (Opuntia ficus - indica Mill) associada a diferentes volumosos em dietas para vacas da raça holandesa em lactação. Acta Scientiarum Animal Sciences, Maringá, v. 29, n. 3, p. 317-324, 2007.

SOUZA, C. M. S.; MEDEIROS, A. N.; FURTADO, D. A.; BATISTA, Â. M. V.; PIMENTA FILHO, E. C.; SILVA, D. S. Desempenho de ovelhas nativas em confinamento recebendo palma forrageira na dieta na região do Semiárido nordestino. Revista Brasileira de Zootecnia, Viçosa, MG, v. 39, n. 5, p. 1146-1156, 2010.

SOUZA, V. M.; CALDEIRA, L. A.; ROCHA JÚNIOR, V. R.; ANTUNES, A. P. S.; RUAS, J. R. M.; SANTANA, P. F.; COSTA, N. M.; BORGES, L. D. A. Efeito de níveis crescentes de ureia na alimentação de vacas sobre o rendimento, composição, perfil de ácidos graxos e sensorial do queijo Minas frescal. Revista Brasileira de Ciência Veterinária, Niterói, v. 22, n. 2, p. 107-113, 2015.

SOYEURT, H.; DEHARENG, F.; MAYERES, P.; BERTOZZI, C.; GENGLER, N. Variation of $\Delta 9-$ desaturase activity in dairy cattle. Journal of Dairy Science, Champaign, v. 91, n. 8, p. 3211-3224, 2008.

ULBRICHT, T. L. V.; SOUTHGATE, D. A. T. Coronary heart disease: seven dietary factors. Lancet, London, v. 338, n. 8773, p. 985-992, 1991.

WANDERLEY, W. L.; FERREIRA, M. A.; ANDRADE, D. K. B.; VÉRAS, A. S. C.; FARIAS, I.; LIMA, L. E.; DIAS, A. M. A. Palma forrageira (Opuntia fícus indica Mill) em substituição à silagem de sorgo (Sorghum bicolor (L.) Moench) na alimentação de vacas leiteiras. Revista Brasileira de Zootecnia, Viçosa, MG, v. 31, n. 1, p. 273-281, 2002. 